\title{
Magiczność słowa we wczesnoindyjskiej refleksji nad językiem
}

\section{Magical Nature of Words in the Early Indian Notions of Language}

\author{
Michat Lipnicki \\ INSTYTUT JĘZYKOZNAWSTWA, UNIWERSYTET IM. ADAMA MICKIEWICZA \\ AL. NIEPODLEGŁOŚCI 4, 61-874 POZNAŃ \\ michal.lipnicki@amu.edu.pl
}

\begin{abstract}
The present paper aims to present the notion of language emerging from the ideas from the early, prephilosophical phase of the development of Indian thought. We start our investigation with the analysis of two Rigvedic hymns (circa $1600 \mathrm{BC}$ ). Then we proceed to some excerpts from Brahmanas texts (circa 1000 BC) and finally we end our inquiry with the analysis of selected parts of the Upanishads (circa $700 \mathrm{BC}-200 \mathrm{CE}$ ).
\end{abstract}

\section{Wstęp}

Zgodnie z tezą, którą w swoim artykule z 1935 roku zatytułowanym O filozofowaniu Hindusów postawil wybitny polski indolog - Stanisław Schayer, genezy filozofii indyjskiej należy poszukiwać $\mathrm{w}$ przedfilozoficznych wierzeniach związanych z pojęciem magii rytualnej.

„Nie będzie na pewno taką przesadą, jeśli powiem, że magja rytualna stała się dla najstarszej filozofji indyjskiej poniekąd tem, czem nauki przyrodnicze dla nowożytnej filozofji europejskiej: a więc obrazem danej empirycznie rzeczywistości, której ukrytą strukturę i prawa należało wyjaśnić i uzasadnić. (...)

Mamy dostateczne powody, aby przypuszczać, że wszystkie kultury przechodzą fazę magicznego myślenia i że leży ona także u podstaw filozofji greckiej. Różnica polega jednak w każdym razie na tem, że w Indjach magja weszła w oficjalny kult, że nie ograniczyła się do sfery niezracjonalizowanego folkloru, lecz została uczenie skodyfikowana przez intelektualną elitę zawodowych 


\section{Michat Lipnicki: Magiczność Stowa we wczesnoindyjskiej refleksji nad językiem}

Likurgów-braminów i wreszcie, co najważniejsze, że właśnie w rękach tej samej bramińskiej elity później zmonopolizowana została spekulacja filozoficzna.” (sic!) (S. Schayer 1988: 137-138)

Postulowana przez Schayera perspektywa patrzenia na rozwój myśli indyjskiej jest już dosyć stara. Współczesna rzeczywistość naukowa przyzwyczaiła nas do bardzo krótkiego „żywota” idei w ich niezmienionej postaci - bywają one szybko modyfikowane, reinterpretowane, a w ostateczności falsyfikowane. Nie inaczej jest $\mathrm{z}$ badaniami nad filozofią indyjską. Od czasów, w których autor Studien zur indischen Logik wystosował swoją propozycję, nasza wiedza o historii filozofii Indii niezwykle się pogłębiła, co zaowocowało, jak się wydaje z perspektywy czasu, bardziej obiektywnym spojrzeniem na jej istotę. Można się zatem zastanawiać, czy odświeżanie pomysłów badaczy z okresu, z którego większość prac posiada już wartość jedynie historyczną, jest uzasadnione. Stoimy na stanowisku, że koncepcje z okresu dominacji innego podejścia badawczego nie muszą być siłą rzeczy nieadekwatne i jako takie niewarte ich przypomnienia tym bardziej, że mogą się one okazać wielce użyteczne w opisie wybranych zagadnień z zakresu filozofii.

Obserwując rozwój wczesnoindyjskiej refleksji nad językiem można dojść do wniosku, że doskonale egzemplifikuje on zasadność podejścia zaproponowanego przez pierwszego dyrektora Wydziału Orientalistyki Uniwersytetu Warszawskiego. Stanisław Schayer rozpoczynał swoją genezę od zbioru tekstów Brahmana (ok X w. p.n.e.) - komentarzy do hymnów wedyjskich (XVI w. p.n.e.). To $\mathrm{w}$ nich doszukiwał się rudymentów magiczności filozofii indyjskiej. W niniejszym artykule postaramy się pokazać, że taka specyfika spekulacji nad zagadnieniami związanymi z językiem jest antycypowana już $w$ najstarszych tekstach indyjskich Wedach. Tym samym zaczniemy naszą analizę od momentu wcześniejszego niż proponował ten wybitny badacz i przebędziemy jedynie „pierwszy etap” historii filozofii indyjskiej - zatrzymując się na wybranych fragmentach zbioru Upaniszady (ok. VII w. p.n.e. - II w. n.e.).

\section{Okres Wed}

Wedy są najstarszymi poświadczonymi tekstami kultury półwyspu indyjskiego oraz jednymi z najstarszych tekstów kultury indoeuropejskiej w ogóle. Data ich powstania nie jest dokładnie znana, najczęściej przyjmuje się, że najstarsze hymny zaliczane do kanonu powstały ok. XIV w. p.n.e. (por. P. Balcerowicz, 2003: 69; M. Kudelska, 2004: 15; J. Kieniewicz, 2003, 40; S. Radhakrishnan I, 1951: 94). Nazwa całego zbioru (veda) oznacza świętą i prawdziwą wiedzę religijną. Tradycyjnie na teksty wedyjskie składały trzy kompilacje hymnów (samihitā). Każda z nich przeznaczona była dla innego kapłana spełniającego określoną funkcję $\mathrm{w}$ rytuale magiczno-religijnym. Najstarszy jest zbiór Rygweda (rgveda) wiedza hymnów, zawierający formuły dla kapłana hotr - wykonującego święte pieśni. Jadźurweda (Yajurveda), zawierająca formuły ofiarne, to 
podręcznik dla adhvaryu - kapłana spełniającego właściwy akt ofiarny. Samaweda (Sāmaveda), to zbiór świętych śpiewów, w którego skład wchodzą wskazówki dla intonującego kapłana zwanego udgātr. Z czasem do Wed dołączony został, funkcjonujący wcześniej w użyciu potocznym, zbiór zaklęć - Atharwaweda (Atharvaveda) ${ }^{1}$.

Problemy $\mathrm{z}$ datowaniem powstania Wed wynikają $\mathrm{z}$ faktu, że pierwotnie teksty te nie były zapisywane, a funkcjonowały jedynie w przekazie ustnym. Przez całe stulecia pieczołowicie kultywowana była tradycyjna linia przekazu, zgodnie z którą uczeń - neofita sztuki kapłańskiej, uczył się poszczególnych hymnów od swojego nauczyciela (guru). Niezwykle istotne było, aby tekst Wed nie ulegał absolutnie żadnym zmianom, dlatego nauka obejmowała nie tylko zapamiętywanie poszczególnych hymnów, lecz również pojedynczych słów w tych hymnach użytych ${ }^{2}$. Procedura ta miała zapobiec możliwości zmienienia formy przy jednoczesnym zachowaniu literalnej treści, np. zastępując określone wyrażenie jego synonimem. Wierzono, że zmiana tekstu Wed mogłaby mieć różne katastrofalne konsekwencje dla świata, łącznie z zawaleniem się jego porządku (rta).

Omawiając określone koncepcje wedyjskie powinno się mieć na uwadze, że posiadają one przedfilozoficzny charakter i zawierają spekulacje religijne o wyraźnym rysie mitologicznym. Mimo tego są one niezwykle istotne dla badania rozwoju jakiegokolwiek aspektu kultury indyjskiej. Odnośnie do refleksji nad językiem należy zaznaczyć, że przedmiotem zainteresowania nie jest język „w ogóle”, lecz jego specyficzna odmiana, jaką jest mowa sakralna, wypełniona magiczną mocą (brahman)3, pozwalająca wpływać na kształt świata bądź bezpośrednio, bądź pośrednio (wywołując boskie interwencje). Rozdzielenie od siebie świętej mowy sakralnej i mowy potocznej jest w Wedach sygnalizowane i uwzględniane w interpretacjach (por. B. Koc 2002: 44-45; F. Staal 1977: 321). Poniższy hymn Rygwedy 10.71. mówi między innymi o tym wydarzeniu.

„Bryhaspati! Pierwszy początek Mowy [powstał], gdy się do nadawania imion zabrali.

Co w nich najlepsze, co bez skazy było -

- to ukryte w nich dzięki miłości ujawniono.

\footnotetext{
${ }^{1}$ Niektórzy badacze sugerują, że hymny Atharwawedy, pomimo że dołączone do kanonu jako ostanie, są niemal tak stare, jak Rygweda (por. M. Kudelska, 2004: 15). E. Frauwallner (1990: 85) w swojej Historii filozofii indyjskiej omawiając Wedy (niezwykle lapidarnie) wymienia tylko trzy pierwsze samihitā, pomijając Atharwawedę.

2 Ostateczna kanonizacja Wed miała nastąpić w połowie pierwszego tysiąclecia przed naszą erą. Cały zabieg polegał na ustaleniu formy Rygwedy przez wyodrębnienie z tzw. mowy ciągłej (samhitā) pojedynczych wyrażeń umożliwiających analizę leksykalną (padapātha) tekstu. Czynu tego miał dokonać mędrzec Śākalya, wyodrębniając brzmienie poszczególnych słów poprzez usunięcie sandhi międzywyrazowego i wewnątrzwyrazowego, charakterystycznego dla języka wedyjskiego tak samo, jak później dla sanskrytu. Doniosłość całego zabiegu jest o tyle znacząca, że F. Staal nazywa jego twórcę pierwszym językoznawcą (F. Staal 2008: 77).

3 Termin brahman jest również synonimem vāc i oznacza język.
} 


\section{Michat Lipnicki: Magiczność Stowa we wczesnoindyjskiej refleksji nad językiem}

Gdy niczym ziarno sitem oczyszczając, mędrcy ukształtowali Mowę umysłem, wtedy towarzysze, wspólnotę doceniając, [ujrzeli] na Mowie odciśnięty ich pomyślny znak.

Dzięki ofierze poszli tropem Mowy

[i] znaleźli ją przenikniętą u wieszczów.

Zabrawszy ją, rozdzielili różnorodnie -

- siedmiu piewców opiewa ją wspólnie.

Ktoś chociaż patrzył, nie zobaczył Mowy, inny znów słuchając, nie usłyszy jej, innemu znowu ciało swe odsłania niczym spragniona, pięknie odziana żona mężowi." (tłum. B. Koc $)^{4}$

Podział języka na mowę sakralną i potoczną, zgodnie z przytaczanym fragmentem, nastąpił w procesie jego „oczyszczania”. Można w tym miejscu zadać pytanie o stosunek języka do mowy. W Rygwedzie przedmiotem rozważań jest mowa sakralna. Musieli zatem autorzy Wed dysponować jakimś szerszym pojęciem języka, skoro potrafili wyodrębnić z niego mowę, która dodatkowo charakteryzuje się szczególnymi własnościami. Zgodnie z interpretacją F. Staala (2008: 292) język jest tutaj zjawiskiem umysłowym, istniejącym w formie zinternalizowanego tworu, którego jednym $\mathrm{z}$ percypowalnych aspektów jest mowa. Poprzez oczyszczanie języka mowa sakralna została eksternalizowana i uzyskała byt obiektywny, pozostając jednak $\mathrm{w}$ ścisłym genetycznym związku $\mathrm{z}$ procesami umysłowymi, które ukształtowały jej specyfikę. Umysł (manas) jest to wewnętrzny, tzn. umieszczony w ciele organ, typowy dla ludzi i bogów. Bez względu na lokalizację umysł istnieje niezależnie, jego istota nie jest zdeterminowana życiem lub śmiercią „nosiciela”. Mowa sakralna w tej interpretacji jest różna od języka funkcjonującego jako domena umysłowa. Mamy tu do czynienia z dwoma podziałami: język - mowa oraz mowa sakralna - mowa potoczna. Aby uczynić drugi z podziałów bardziej wyrazistym, należy opisać kilka specyficznych cech mowy sakralnej.

4 Ten sam fragment w tlumaczeniu F. Staala (1975: 322):

(1) Brhaspati! When they came forth to establish the first beginning of language, setting up names, what had been hidden in them as their best and purest good became manifest through love.

(2) When the sages fashioned language with their thought, filtering it like parched grain through a sieve, friends recognized their friendship. Their beauty is marked on the language.

(3) They traced the course of language through the sacrifice: they found it embodied in the seers. They gained access to it and distributed it widely; the seven chanters cheered them.

(4) Many who look do not see language, many who listen do not hear it. It reveals itself like like a loving and well adorned wife to her husband. 
Przede wszystkim konieczne jest uwzględnienie pojawiającego się $\mathrm{w}$ przytaczanym hymnie zagadnienia nazw i nazywania obiektów. Nawiązując do omawianego teksu, F. Staal pisze:
„(...) in the activity of verbal creation, thought and language are filtered. This filtering is a purification, which brings the sacred powers of language to the surface ( $F$. Staal 1975: 321).5"

Święte moce (brahman), pojawiające się w procesie oczyszczania języka, to relacje ekwiwalencji, na których opiera się magiczność mowy. Nazwę z jej przedmiotem odniesienia łączy więź magicznej homologii ustalana przez pierwotne nadanie obiektom imion. Jest to moc, dzięki której można w bezpośredni sposób oddziaływać na świat za pomocą słów. W takiej sytuacji nie ma miejsca na konwencjonalność relacji nazwa - przedmiot, ponieważ ta implikuje dowolność i w efekcie zmienność nazw i denotacji ${ }^{6}$. Rezultatem takiej zmiany byłoby zniszczenie związku między nimi i nieskuteczność magii. Aby zachować sztywne powiązanie nazwy i jej denotacji musi dojść do utożsamienia rzeczywistości językowej $\mathrm{z}$ pozajęzykową, podczas którego nazwa staje się jednym z naturalnych aspektów swojej denotacji. Jak zobaczymy w dalszej części pracy, twierdzenie to stanie się kluczowe $\mathrm{w}$ poglądach na język zawartych $\mathrm{w}$ tekstach Upaniszad.

Magiczna moc oddziaływania na świat, która jest zawarta w mowie magicznej, ma wpływ na jej ekskluzywny charakter, co z kolei wiąże się z potrzebą oddzielenia języka sakralnego od potocznego. Rozdźwięk taki następuje nawet $\mathrm{w}$ sytuacji, gdy mowa magiczna charakteryzuje się strukturalnym izomorfizmem z mową potoczną. Często jest tak, że w społecznościach magicznych język sakralny znacznie różni się od swojego potocznego odpowiednika (szczególnie na poziomie leksykalnym). $\mathrm{Na}$ ten fakt wskazywał Bronisław Malinowski (1988: 343-385) badając kulturę plemion wysp Trobrianda. Mowa magiczna, pomimo że jest zrozumiała dla wszystkich członków danej społeczności, to może być używana jedynie przez wąską grupę obdarzonych umiejętnościami kontrolowania mocy zawartej w mowie czarowników-szamanów. Wiąże się to ze specyfiką spojrzenia na język charakteryzującego kultury pierwotne, gdzie często znaczenie semantyczne wyrażeń bywa przesłaniane przez ich funkcję magiczną - mówić, to wywierać konkretny wpływ na rzeczywistość pozajęzykową (W. Burszta 2009: 17). Tak też w cytowanym fragmencie

\footnotetext{
${ }^{5}$ Warto $\mathrm{w}$ tym miejscu odnotować, że w późniejszej interpretacji tego hymnu ten sam autor dewaloryzuje rolę fragmentu mówiącego o nazywaniu. Twierdzi on, że słowa te zostały napisane $\mathrm{w}$ poetyckim natchnieniu i nie należy temu wersowi poświęcać nadmiernej uwagi (F. Staal 2008: 292).

6 We współczesnej tradycji terminologicznej „denotacja” posiada dwa znaczenia. Po pierwsze: $\mathrm{w}$ wąskim rozumieniu jest to zbiór desygnatów, czyli każdego poszczególnego obiektu, o którym można zgodnie z prawdą daną nazwę orzec. Po drugie: w szerokim rozumieniu, oznacza on po prostu wszelkie odniesienie danej nazwy. W niniejszym artykule będziemy używać tego terminu zgodnie z jego drugim, szerokim rozumieniem.
} 
hymnu 10.71. nie każdy został obdarowany możliwością używania mowy sakralnej. Tylko nieliczni bramini dostąpili tego zaszczytu, reszta została wykluczona $\mathrm{z}$ tego grona. Tym samym operowanie magiczną mocą słów stało się ekskluzywną domeną predysponowanych do tego kapłanów.

Mitologiczność sprzyja personifikacji opisywanych zjawisk - żywioły i zjawiska przyrodnicze i mowa w Wedach otrzymują cielesność boską. We fragmencie cytowanego poniżej hymnu Rygwedy 10.125. to właśnie mowa występuje w funkcji podmiotu lirycznego.

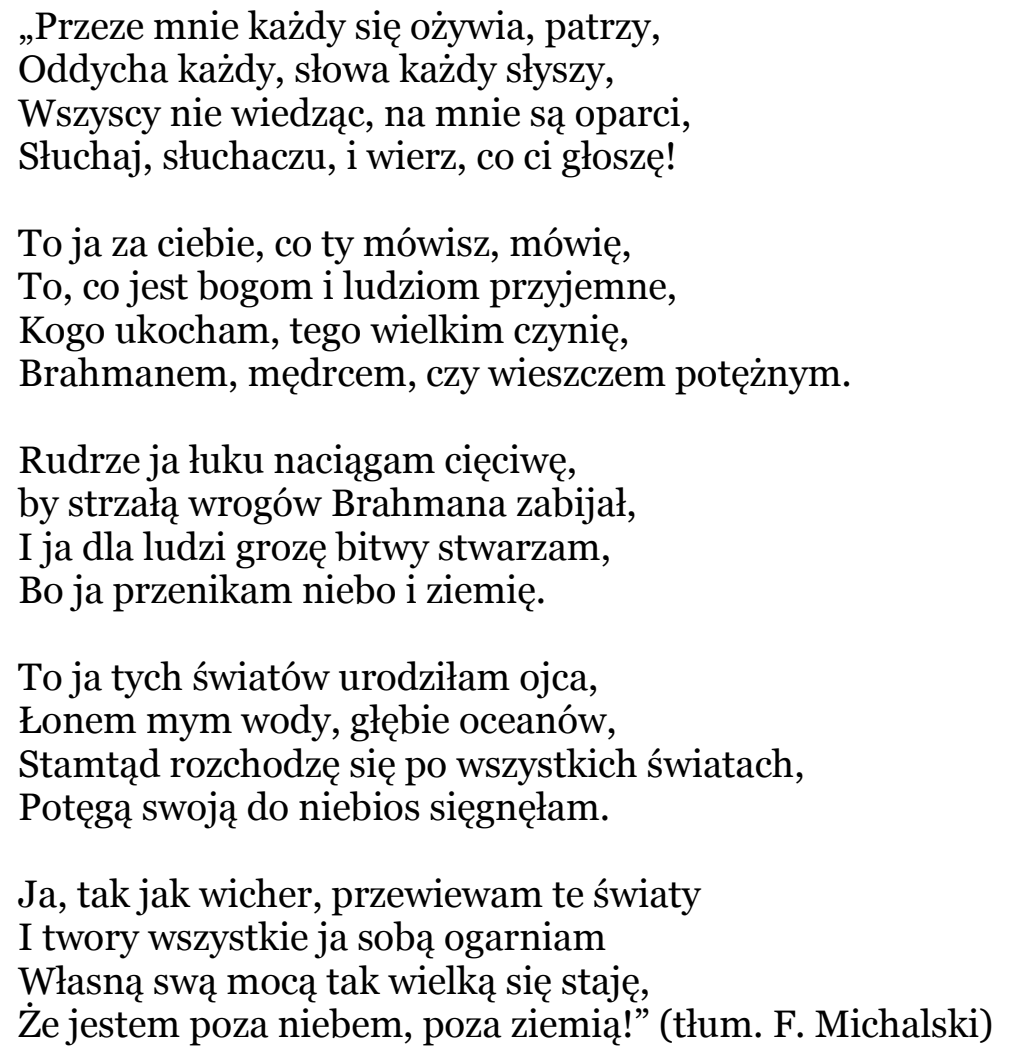

W swojej niezwykle lapidarnej interpretacji powyższego hymnu $\mathrm{F}$. Michalski (1971: 157) pisze: „Hymn filozoficzny, dowodzi nierealności świata zewnętrznego". Nie jest jasne, wobec kogo ów świat miałby być zewnętrzny i na czym miałaby polegać jego nierealność. Wnioski wyciągnięte przez Franciszka Michalskiego są zbyt daleko idące. W naszej interpretacji zadowalamy się konstatacją, że mowa kreuje świat, z tym że nie jest to akt stwarzania $\mathrm{w}$ sensie kosmologicznym, świat jako taki już istnieje, a raczej kształtowanie zastanego tworu poprzez bezpośredni wpływ na jego strukturę - w sposób magiczny i przy pomocy boskich interwencji, które są efektem określonych działań rytualnych wspartych właściwościami mowy sakralnej. Dla badaczy nastawionych komparatystycznie może się wydawać szczególnie atrakcyjnym zadaniem rozpatrzenie tego wpływu w kategoriach pośrednich, gdzie mowa miałaby wpływać na nasze postrzeganie świata przez narzucanie określonych wzorców jego kategoryzowania, co nasuwałoby skojarzenia z hipotezą relatywizmu językowego. Uważamy, że w ujęciu wedyjskim wpływ mowy 
na kształt rzeczywistości jest rozpatrywany jedynie w sensie mitologicznym i porównywanie go z hipotezą Sapira-Whorfa byłoby uwikłaniem się w metodologiczny błąd anachronizmu, ponieważ implikuje ono, jakoby mieszkańcy Półwyspu Indyjskiego w okresie wedyjskim dysponowali o wiele bardziej złożonym pojęciem języka, niż miało to miejsce w rzeczywistości.

W niniejszym podrozdziale wskazywaliśmy, że $\mathrm{w}$ Wedach należy szukać początków sztywnego powiązania nazwy i jej przedmiotu odniesienia, która to relacja istnieje w formie magicznej homologii. Dzięki nazwie możliwe jest wpływanie na kształt rzeczywistości. W dalszej części niniejszego artykułu będziemy starali się pokazać, że takie postrzeganie relacji nazywania będzie wpływało na poglądy głoszone $\mathrm{w}$ tej materii $\mathrm{w}$ Upaniszadach. Wcześniej jednak przyjrzymy się, jak interesujące nas zagadnienie było rozważane $\mathrm{w}$ tekstach Brahmanów (brahmana) komentarzy do Wed.

\section{Brahmany}

Uważa się, że Brahmany powstały na przełomie drugiego i pierwszego tysiąclecia p.n.e. (por. P. Balcerowicz 2003: 69; M. Kudelska 2004: 16). Na płaszczyźnie merytorycznej możne je traktować jako wyraz okresu przejściowego $\mathrm{w}$ historii myśli indyjskiej. Z jednej strony kontynuują dyskurs mitologiczny znany $\mathrm{z}$ Wed, z drugiej zaś ujawniają bardziej intelektualne próby wyjaśniani zjawisk należących do sfery religijnej. W szczególności dotyczy to rytuałów ofiarnych, które zostały szczegółowo opisane i ustalono ścisłe wytyczne odnośnie do ich poprawnego przeprowadzania. Rozwinięte i poddane procedurze klasyfikacji zostaje pojęcie mocy lączącej dwa z pozoru heterogeniczne obiekty relacją magicznej ekwiwalencji. Właśnie w ustalaniu kryterium klasyfikacyjnego homologii magicznych widoczne stają się próby wyjaśniania o charakterze intelektualnym, odwołującego się nie tylko do mitologii, ale też do empirii oraz wiedzy apriorycznej.

Istota magicznej homologii polega na przekonaniu, że różnego rodzaju relacje łączące zjawiska w świecie postrzegalnym są odbiciami związków zachodzących na „głębszym”, niedostępnym zmysłom poziomie istnienia. Istnienie relacji ekwiwalencji działających na poziomie transcendentnym umożliwia magiczne oddziaływanie na jedno zjawisko przy pomocy innego, pozornie heterogenicznego w stosunku do pierwszego.

W Brahmanach wyróżnione zostały cztery typy ekwiwalencji tego typu (P. Balcerowicz 2003: $70-75)$ :

1. liczbowe,

2. etymologiczne,

3. mitologiczne,

4. strukturalne.

Homologia liczbowa łączy byty dające się scharakteryzować za pomocą tych samych miar liczbowych. 


\title{
Michał Lipnicki: Magiczność Stowa we wczesnoindyjskiej refleksji nad
} językiem

\author{
„«Rok» (samivatsara) składa się $\mathrm{z}$ czterech sylab, \\ «ofiarnik» (yajamāna) składa się z czterech sylab: zatem \\ rok i ofiarnik są tożsame." (Śatapathabrāhmana 12.3.2. \\ cyt. za P. Balcerowicz 2003: 71)
}

W cytowanym fragmencie homologia działająca na poziomie wyrażeń języka, wpływa na ekwiwalencję ich denotacji. Postrzegalna homologia fonetyczna jest tutaj odpowiedzialna za transcendentną homologię genetyczną dwóch heterogenicznych obiektów. Nazwa jest ściśle utożsamiana ze swoim przedmiotem odniesienia, tak jak to miało miejsce w Wedach. To sztywne powiązanie znaku dźwiękowego z obiektem, na który wskazuje, pozwala rzutować homologie z płaszczyzny językowej na rzeczywistość pozajęzykową. W przypadku uznania dowolności relacji nazywania takie przejście byłoby niemożliwe. $\mathrm{Na}$ tej samej zasadzie działają ekwiwalencje etymologiczne opierające się na pokrewieństwie etymologicznym wyrażeń oznaczających te obiekty ${ }^{7}$.

\section{„Wszyscy ci oto bogowie przybyli do jego zabudowań: oto zamieszkują (upavasanti) w jego zabudowaniach, zatem jest to dzień postu (upavasatha)." (Satapathabrāhmana 1.1.1.8. cyt. za P. Balcerowicz 2003: 72)}

Tak jak w przypadku homologii liczbowych obserwuje się w homologiach etymologicznych swobodne przechodzenie $\mathrm{z}$ poziomu językowego na pozajęzykowy.

Wyłaniająca się $\mathrm{z}$ dwóch przedstawionych typów homologii idea magiczności zostaje rozwinięta. Nie sprowadza się już do prostej magicznej zależności słowo (czyn) - moc magiczna - przedmiot odniesienia. Nie oddziałuje się tutaj bezpośrednio na przedmiot przy pomocy słowa czy też czynu, ale dzięki ekwiwalencji na doświadczalnym poziomie rzeczywistości (np. językowym), odkrywa się ekwiwalencję na poziomie transcendentnym między zjawiskami innymi niż językowe. Dwa pozostałe typy homologii są już mniej interesujące ze względu na temat naszych rozważań. Trzeci typ homologii opiera się na wspólnym mitologicznym rodowodzie obiektów czy zjawisk, a czwarty - strukturalny, postuluje powiązanie ze sobą niezależnych przedmiotów na podstawie ich podobnej budowy.

Ciekawym zabiegiem $\mathrm{z}$ punktu widzenia współczesnej antropologii kulturowej może okazać się zbadanie koncepcji magii wyłaniającej się z Brahmanów, używając metodologii typowych dla tej dziedziny. Skupimy się tutaj na metodzie zaproponowanej przez C. Levi-Straussa, która opiera się na pojęciach typowych dla strukturalizmu. Do analiz antropologicznych wykorzystuje się w niej ukute przez R. Jakobsona pojęcia metafory i metonimii oraz klasyfikację i interpretację magii zaproponowaną przez G. Frazera. Związek metaforyczny między obiektami oznacza symbolizowanie semantyczne (relacja paradygmatyczna), natomiast związek metonimiczny odpowiada relacji przyczynowej tudzież relacji genetycznej przyległości

7 Oczywiście etymologie, na których opiera się ten typ homologii, zaliczyć należy do ludowych, często opierających się na przypadkowych zbieżnościach fonologicznych. 
(relacja syntagmatyczna) (J. Kmita 2001: 11-12). Czynność magiczna, wchodząca w skład szerszego sposobu myślenia nazywanego przez autora Antropologii strukturalnej mito-logiką, polega na ciągłym zastępowaniu związków symbolicznych przez przyczynowe i odwrotnie - przyczynowych przez symboliczne. Istotę tych przejść obrazuje następujący przykład: relacja przyczynowa łącząca określoną dzidę $\mathrm{z}$ raną, która została nią zadana, zostaje zastąpiona związkiem symbolicznym: określona dzida określona rana. Ta z kolei może przejść ponowną transformację w związek przyczynowy - jeżeli poprzez manipulację dzidą oddziałuje się w sposób magiczny na ranę (J. Kmita 2001: 13). W analogiczny sposób można próbować opisać typy ekwiwalencji magicznych pojawiające się $\mathrm{w}$ Brahmanach. Przyjrzyjmy się homologii etymologicznej:

1. Związek metonimiczny opierający się na przyległości genetycznej: wyrażenie (1) „post” - wyrażenie (2) „obecność bogów”.

2. Związek metonimiczny zastępowany jest związkiem metaforycznym: wyrażenie (1) zaczyna symbolizować wyrażenie (2).

3. Zastąpienie związku metaforycznego - metonimicznym: przedmiot odniesienia (1) - przedmiot odniesienia (2), poszczenie sprowadza bóstwa do domostwa poszczącego.

Podejście strukturalistyczne zostało mocno skrytykowane, szczególnie na gruncie etnolingwistyki. Przeciwnicy metody strukturalistycznej twierdzą, że zakłada ona, iż społeczeństwa pierwotne były $w$ stanie dokonywać rozróżnień między związkami metonimicznymi i metaforycznymi, co wydaje się zbyt odważną hipotezą. W rzeczywistości myślenie (i mówienie) społeczeństw pierwotnych opiera się na swoistym synkretyzmie dwóch typów relacji i nie może być mowy o żadnych przejściach między nimi (por. W. Burszta 1991). Podobnie opozycyjna w stosunku do strukturalizmu jest, przywoływana już w niniejszym artykule, B. Malinowskiego teoria języka magicznego. Autor Ogrodów koralowych twierdzi, że język pierwotny (magiczny) powinno się analizować z perspektywy pragmatycznej, a nie semantycznej. Funkcja symboliczna języka jest w nim mniej istotna, niż jej funkcja sprawcza. Nie jest naszym celem referowanie zasygnalizowanego sporu, dlatego poprzestaniemy na tych bardzo pobieżnych uwagach i przejdziemy do kolejnego etapu w rozwoju myśli indyjskiej - okresu Upaniszad.

\section{Okres Upaniszad}

Upaniszady (upaniṣad) to kolejna grupa tekstów komentujących hymny wedyjskie. Jest to zbiór o wielkim znaczeniu dla filozofii indyjskiej, ponieważ to właśnie w nim po raz pierwszy w historii półwyspu indyjskiego pojawiają się fragmenty, które zalicza się do spekulacji czysto filozoficznej. Kompilacja tekstów wchodzących w skład Upaniszad trwała przez blisko tysiąc lat (circa VII-VI w. p.n.e. - II w. n.e.). Długi okres dzielący poszczególne fragmenty oraz spora liczba autorów sprawia, że światopogląd wyłaniający się z Upaniszad często jest niespójny, a czasami nawet sprzeczny. Każda z ksiąg zaliczanych do kanonu przynależy do 
Michał Lipnicki: Magiczność Stowa we wczesnoindyjskiej refleksji nad językiem

jednej z czterech Wed, którą komentuje. E. Frauwallner (1990: 88) uważa, że z filozoficznego punktu widzenia istotnych jest tylko kilka z nich, są to: należące do Rygwedy Aitereja (Aitareya) oraz Kauszitaki (Kausịtaki); należące do Jadżurwedy Taitirija (Taittirìya), Brihadaranjaka (Brhadāranyaka) oraz Iśa (İ́sā); należące do Samawedy Czhandogja (Chāndogya) oraz Kena (Kena).

W kwestiach filozoficznych $\mathrm{w}$ Upaniszadach pierwszorzędną rolę odgrywają rozważania epistemologiczne. Wynika to z faktu, że w Indiach wiedza pełniła ważną funkcję soteriologiczną - była warunkiem koniecznym osiągnięcia stanu wyzwolenia (moksa). Tak też zagadnienia związane $\mathrm{z}$ pojęciem języka są rozpatrywane $\mathrm{w}$ powiązaniu $\mathrm{z}$ ideami epistemologicznymi oraz soteriologicznymi. Istotę upaniszadowego poglądu na język, a w szczególności na relację nazywania, odnajdujemy w dwóch fragmentach Upaniszady Brihadaranjaka:

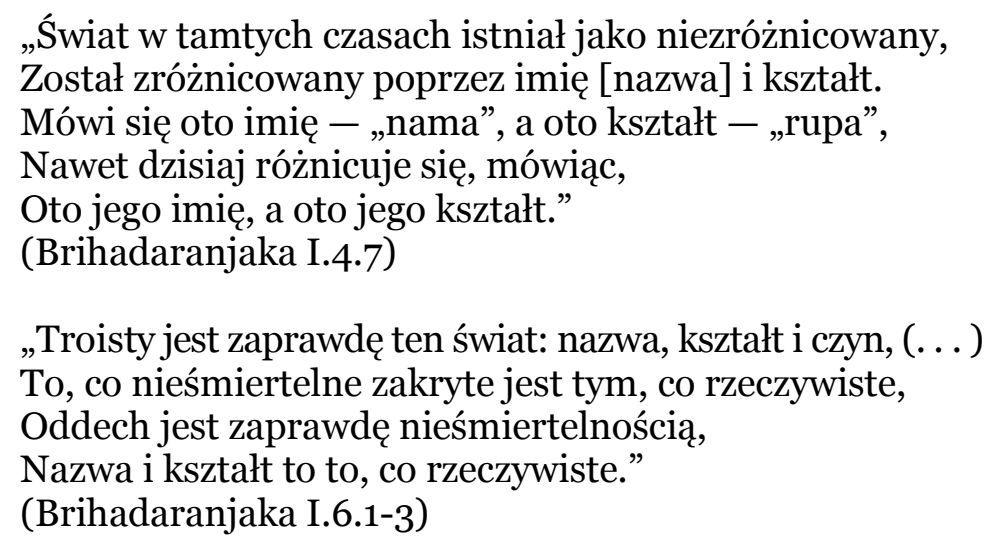

$\mathrm{W}$ pierwszym fragmencie postulowany jest naturalizm relacji nazywania. Nazwa odnosi się do rzeczywistości pozajęzykowej nie na mocy konwencji, lecz dzięki naturalnemu związkowi ze swoim przedmiotem odniesienia. Każdy obiekt został stworzony w taki sposób, że posiada odpowiednią nazwę i tylko ona jest mu właściwa. Naturalność w takim ujęciu polega na niezmienności zasad leżących u podstaw danego zjawiska, tutaj przyporządkowania nazw obiektom. Reguły odpowiedzialne za to przyporządkowanie muszą leżeć poza obszarami woli ludzkiej, albowiem tylko wtedy mogą uzyskać permanentną trwałość. Można zaryzykować twierdzenie, iż relacja między nazwą a jej denotacją zostaje ustalona na takiej samej zasadzie, na której oparte są wszelkie prawa natury. Jak pokazaliśmy już Wedach i Brahmanach nazwa jest sztywno połączona ze swoją denotacją, natomiast $w$ Upaniszadach nie ma już miejsca na magiczność, związek magicznej homologii został zastąpiony naturalnym odwzorowaniem. Nazwa zaczyna funkcjonować jako własność ulokowana w konkretnym podłożu - swoim przedmiocie odniesienia. Przyjmując terminologię używaną przez semiotykę, powiemy, że w Upaniszadach znaki językowe (wyrazy), są znakami naturalnymi, których istota opiera się na występujących w przyrodzie związkach między zjawiskami, a nie znakami sztucznymi (jak się je widzi współcześnie), wytworzonymi przez kulturę. Istotną cechą nazwy, zgodnie z drugim cytowanym fragmentem, jest jej 
funkcjonalny i genetyczny homomorfizm z kształtem (formą) przedmiotu. Cechą tej drugiej jest epistemologiczna wtórność w stosunku do zmysłu wzroku, a jej istota leży w użyteczności poznawczej, która w kooperacji z odpowiednim zmysłem umożliwia rozpoznawanie obiektów świata zewnętrznego w stosunku do podmiotu poznającego. Tym samym, skoro nazwa jest tożsama z kształtem, można się spodziewać, że również będzie pełnić ważne funkcje w procesie poznania.

Tak więc każdy przedmiot posiada przyporządkowaną mu naturalnie nazwę, przy pomocy której orzeka się poprawnie o tym obiekcie. Istnienie zatem jest równoważne $\mathrm{z}$ posiadaniem nazwy ${ }^{8}$, a skoro wszystko, co istnieje, posiada nazwę, to znajomość wszelkich nazw równa się znajomości całości istnienia. Język staje się „narzędziem” o niezwykłej wprost doniosłości poznawczej - umożliwia nam poznawanie całości bytu. Warto jednak zauważyć, studząc nieco ten „epistemologiczny entuzjazm”, że rzeczywistość, poznawana w ten konceptualny sposób, przesłania to, co nieśmiertelne - absolut, rzeczywistość ostateczną.

„Jedni powiadają, iż tchnienia staja się jednością, Gdyż w innym wypadku nie można by równocześnie

Poznać nazwy poprzez słowa [mowę], kształtu poprzez wzrok,

Dźwięku poprzez słuch, myślenia poprzez umysł,

Tchnienia, zaprawdę stając się jednym, Pozwalają poznać wszystko jedno po drugim.

(...)

Mowa to jedna część z mądrości wydzielona,

Nazwa jest jej zewnętrznym odpowiednikiem,

${ }^{8}$ Intuicja ta okaże się niezwykle istotna w dalszym ksztaltowaniu myśli indyjskiej. Jednak przeciwko takiemu naturalistyczno-realistycznemu rozumieniu relacji nazwa - denotacja $\mathrm{z}$ całą stanowczością wystąpią buddyści, którzy już w najstarszych sutrach kanonu palijskiego opowiadają się za stanowiskiem konwencjonalistycznym:

"It was said, do not insist for local expressions and do not over ride the popular usage. Why was it said so? Bhikkhus, how is there insistence for local expressions and how is the popular usage over ridden? Bhikkhus, in a certain state the bowl is known as Pàtãti, in another Pattaü, in another Vitthaü, in another Saràvaõ, in another Dhàropan, in another Poõan, and Pisãlan in yet another. By whatever name it is known in that and other state, it is taken as the highest truth and all else is not the truth. This is insisting for local expressions and over riding the popular usage." (Aranavibhanga Sutta; Majjhima Nikaya III).

W dalszym rozwoju filozofii ortodoksyjnej (tj. uznającej autorytet Wed) również pojawiły się szkoły kontestujące Upaniszadowy naturalizm. W kanonicznym dziele szkoły Nyāya-veiśeșika - Nyāya-sūtra czytamy:

"There is no natural connection between a word and the object signified by it." (Nyāya-sutra 2.1.54.)

"We reply it is through convention that the meaning of word is understood." (Nyāya-sutra 2.1.56.) 
Michat Lipnicki: Magiczność Stowa we wczesnoindyjskiej refleksji nad językiem

$(\ldots)$

Opanowując mowę poprzez mądrość,

Mowa osiąga wszystkie nazwy, (...)"

(Kauszitaki III.2-6)

Zgodnie z interpretacją tego fragmentu dokonaną przez E. Frauwallnera (1990, 119-125) wrażenia zmysłowe są traktowane jako zewnętrzne odpowiedniki zmysłów, natomiast aktywności jako niematerialna kontynuacja narządów. Tak też nazwa jest zewnętrznym odpowiednikiem mowy, jak oddechu jest zapach, wzroku - kształt, słuchu - dźwięk, języka - smak, rąk - działanie, ciała - mile i przykre doznania, organu rozrodczego - błogość i rozkosz, stóp - poruszanie się, umysłu - myśl (Kauszitaki III.5.). W procesie postrzegania umysł (świadomość) wnika we wzajemnie warunkujące się narządy $\mathrm{i}$ za ich pomocą rozpoznaje przedmioty. Co więcej, bez narządów poznania (prajñāmātara, w tłumaczeniu M. Kudelskiej „elementy mądrości”) nie istniałyby elementy bytu (bhūtamātara, M. Kudelska - „przedmioty doznania”) i odwrotnie bez elementów bytu nie istniałyby narządy poznania. Mowa umieszczona w takim kontekście przyjmuje formę quasi-zmysłu, który umożliwia rozpoznanie swojego zewnętrznego odpowiednika - nazwy, immanentnej cechy przedmiotów. $\mathrm{W}$ ten właśnie sposób zostaje utrwalona mocna poznawcza pozycja mowy, to dzięki mowie zdobywamy wiedzę o świecie zapośredniczoną w relacjach między nazwą i denotacją - dzięki niej rozpoznajemy nazwy, poprzez znajomość nazw poznajemy rzeczywistość.

Związek między zagadnieniami języka i poznaniem był również rozważany w Starożytności na gruncie filozofii greckiej. W dialogu Kratylos Platon opisuje dwa stanowiska w kwestii charakteru relacji nazywania - naturalistyczne reprezentowane przez Kratylosa i konwencjonalistyczne, którego zwolennikiem był Hermogenes, funkcję arbitra w sporze pelni Sokrates. Poglądy Kratylosa są zbliżone do tych prezentowanych w Upaniszadach, zwięzłą ich wykładnię zawiera sentencja:

„Ten tu oto Kratylos - Sokratesie - mówi, że dla każdej rzeczy istnieje właściwa jej nazwa, a nie jest to nazwą, gdy jacyś ludzie dowolnie oznaczają jakąś rzecz, stosując do niej jakąś cząstkę własnego głosu (...).” (Platon 1984: 71)

Kratylos opowiada się za stanowiskiem głoszącym, że nazwy (jak i język w ogóle) mają naturalną genezę, czyli każdemu obiektowi przysługuje „Z góry" ustalona nazwa i tylko tą nazwą można zgodnie z prawdą orzekać o danym przedmiocie. Właściwa nazwa jest związana $\mathrm{z}$ „naturą” denotacji, która jest niezależna od jakichkolwiek ludzkich aktów wolicjonalnych. Nie jest możliwe, aby człowiek mógł wybierać nazwę zgodnie ze swoją wolą. Może ewentualnie próbować ją trafnie bądź nie odgadnąć. Tak jak myśliciele indyjscy uważa on, że nazwy są nierozerwalnie połączone ze swoimi denotacjami. Implikacje natury epistemologicznej omawianego stanowiska ujawnia Sokrates, pytając, czy skoro nazwy odpowiadają naturze rzeczy, to czy znajomość nazw jest równoznaczna $\mathrm{z}$ wiedzą $\mathrm{o}$ rzeczywistości? Odpowiedź na postawione pytanie (zgodna z poglądami 
Platona) jest negatywna - prawdziwa wiedza na temat rzeczywistości wychodzi od obiektów, a nie od nazw (I. Dąmbska 1984: 21). Zaprezentowane zbieżności pokazują, że naturalistyczny pogląd na relację nazywania nie jest wymysłem czysto indyjskim i przedstawia pewien istotny w filozofii języka nurt niezrelatywizowany do pojedynczej kultury $\mathrm{i}$ obszaru geograficznego.

Omawiając dotychczas wczesnoindyjską refleksję nad językiem celowo unikaliśmy (w miarę możliwości) bezpośredniego odwoływania się do pojęcia znaczenia/oznaczania. Zamiast tego używaliśmy zwrotu „relacja nazywania”. $\mathrm{W}$ ten sposób chcieliśmy wskazać, że spekulacje wczesnoindyjskie, szczególnie te $\mathrm{z}$ okresu Upaniszad nie podejmują explicite zagadnień semantycznych sensu stricto. Rozważania na temat związku między nazwą a jej denotacją dotyczą procesu, w którym nazwy zostają przyporządkowane określonym obiektom. Upaniszady zatrzymują się na tym przedsemantycznym poziomie ontologicznym, zadowalając się przyjęciem związku określonego typu bez rozpatrywania implikacji, jakie on niesie dla koncepcji znaku, jego funkcji oraz sposobu łączenia się z obiektami na poziomie semantycznym. Co prawda można próbować rekonstruować teorię znaczenia stojącą implicite za tego typu spekulacjami (co poniżej czynimy), jak to jednak zazwyczaj bywa w tego typu przedsięwzięciach, należy zachować niezwykłą ostrożność, by nie włożyć w myśli Starożytnych naszych własnych założeń, bądź oczekiwań, jakie w stosunku do ich formy żywimy.

Spoglądając na refleksję wczesnoindyjską, dochodzi się do wniosku, że prezentowane stanowisko naturalistyczne wiąże się z silnym realizmem znaczeniowym. Nazwa i jej denotacja są połączone bezpośrednio relacją o charakterze naturalnym, a nie konwencjonalnym, nazwa wskazuje na obiektywny przedmiot istniejący poza podmiotem. Oznacza przedmiot $\mathrm{w}$ sposób bezpośredni, wskazując wprost na swoją denotację. Nie pojawia się też rozróżnienie znaczenia i obiektu znaczonego, które współcześnie obrazuje się w postaci tzw. trójkąta semantycznego zaproponowanego przez Ogdena i Richarda (P. Guirard 1976: 21).

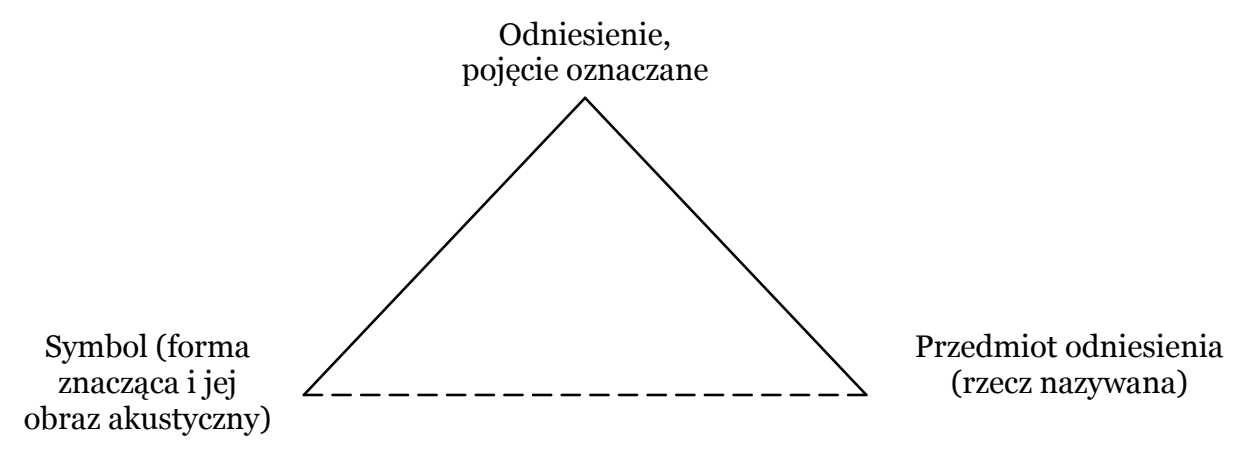

Rysunek 1. Trójkąt semantyczny 
Michał Lipnicki: Magiczność Stowa we wczesnoindyjskiej refleksji nad językiem

Widać na nim brak bezpośredniego związku (linia przerywana) między nazwą (symbolem) a przedmiotem odniesienia. Znaczenie jest zapośredniczone przez obiekt natury psychicznej - pojęcie. W Indiach okresu Upaniszad należałoby zrezygnować ze znajdującego się na wierzchołku trójkąta pojęcia, które nie pojawia się w omawianych fragmentach. Możliwe byłoby całkowite odrzucenie obiektu znajdującego się na wierzchołku omawianego trójkąta i poprzestanie na prostej liniowej odpowiedniości:

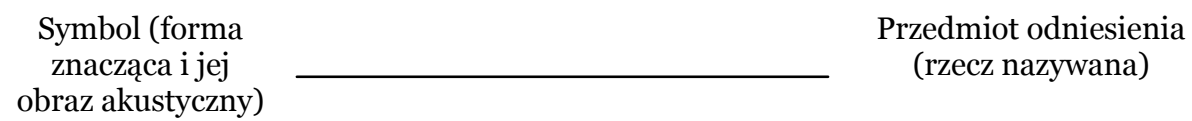

Rysunek 2.

Taka transformacja Rysunku 1. sugerowałaby jednak, że w Upaniszadach nie pojawiają się fragmenty mówiące o związkach między umysłem (manas) a językiem, co nie jest prawdą. Jak pokazywaliśmy, już w Wedach (por. Rygweda 10.71.) pojawiają się intuicje lączące język z umysłem. W Upaniszadach są one, co prawda, niezwykle sporadyczne (por. Brihadaranjaka I.5.8), ale pozwalają uwzględnić miejsce umysłu $\mathrm{w}$ powyższym schemacie - zastępując nim „pojęcie”. Czyniąc tak, otrzymujemy „negatyw” schematu z Rysunku 1.

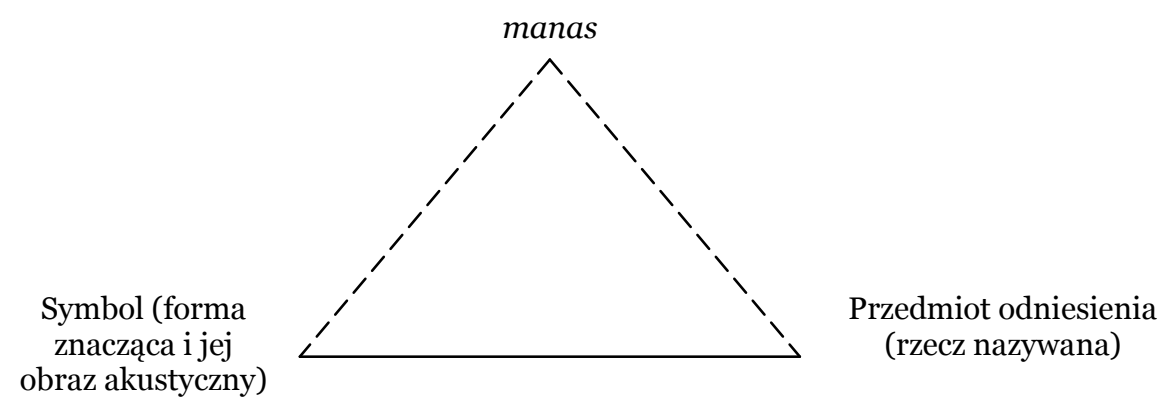

Rysunek 3 .

Manas przemieszcza się między narządami zmysłów i odbiera bodźce dopływające z zewnątrz, by następnie przekazać je duszy (ātman). Sygnały odbierane przez umysł nie są przez niego ksztaltowane - przedmiot ma taką formę, w jakiej objawia się zmysłom. Nazwa, będąc obiektywną, naturalną cechą przedmiotu, jest również poza wolicjonalnymi możliwościami umysłu. Jak mówi fragment Upaniszady Kauszitaki III.26., nazwę poznajemy dzięki mowie, ta z kolei jest inicjowana przez umysł, który dysponując „mową-detektorem”, pomimo że nie jest w stanie 
wpływać na relację nazwa - przedmiot, jest odpowiedzialny za jej poznanie i uzyskanie wiedzy na jej temat. Nie jest on pośrednikiem między nazwą a denotacją, tak jak „pojęcie” w schemacie Ogdena i Richarda, lecz jest narządem umożliwiającym rozpoznanie przedmiotu, nazwy oraz naturalnego związku zachodzącego między nimi. Relacja wyrażona linią przerywaną na Rysunku 3. jest zatem innego typu niż na Rysunku 1. manas obejmuje całościowo związek przedstawiony na Rysunku 2. Myśl ta z dzisiejszej perspektywy może wydawać się naiwna, należy jednak pamiętać, że omawiamy zaczątki myśli filozoficznej, które później rozwiną się do wysoce szczegółowych i ciekawych rozważań, nieustępujących głębią swoich dociekań europejskiej filozofii języka. Przyjmując zaprezentowane intuicje można by poszukiwać ewentualnych zbieżności z myślą europejską w tzw. denotacyjnej koncepcji znaczenia. Zgodnie z nią nazwa jest sztywno powiązana ze swoim przedmiotem odniesienia, a właściwego znaczenia wyrażeń należy szukać w rzeczywistości pozajęzykowej. W podejściu tym można wyróżnić dwa główne nurty: (a) umieszczający znaczenie w dziedzinie bytu obiektywnego i realnego (direct reference theory); (b) umieszczający znaczenie w sferze psychcznej lub obiektywno-idealnej (ideational reference theory). Zwolennicy pierwszego poglądu twierdzą, że znaczeniem wyrażeń są ich istniejące realnie i obiektywnie odniesienia przedmiotowe: dla nazw generalnych - zbiory obiektów spełniających daną nazwę; dla nazw jednostkowych (i deskrypcji określonych) szczególny obiekt jednostkowy. Zwolennicy drugiego podejścia twierdzą, że słowa, nie odnoszą się do rzeczywistości zewnętrznej $\mathrm{w}$ stosunku do podmiotów ją poznających, lecz do ich zinternalizowanych reprezentacji, które są tworzone na podstawie doświadczenia (S. Chapman 2000: 10). Do zwolenników pierwszego podejścia zaliczyć można m.in. J.S. Milla, B. Russella i S. Kripkego. Opozycję w stosunku do nich stanowią m.in. tacy myśliciele, jak Arystoteles, E. Husserl, czy P. Strawson. ${ }^{9}$ Trudno jednak porównywać koncepcje wczesnoindyjskie $\mathrm{z}$ konkretnymy poglądami któregolwiek z wymienionych europejskich filozofów. Współczesne teorie, od Milla poczynając, operują pojęciami i wypływającymi $z$ nich rozróżnieniami, które w okresie Upaniszad były całkowicie obce myślicielom indyjskim, np. pojęcia denotacji i konotacji (sensie i znaczeniu w terminologii Fregego). Niezwykle istotne okazuje się rozróżnienie na nazwy generalne i indywidualne oraz wypływające $\mathrm{z}$ tego podziału różnice w znaczeniu. Postulowanie istnienia tego typu pojęć, wyznaczających kierunek rozwoju współczesnej filozofii języka i semantyki, chociażby na poziomie podświadomości myślicieli indyjskich, uprawniałoby twierdzenie, że są zawarte implicite w tekstach Upaniszad. Twierdzenie takie jest jednak sporym nadużyciem i uwikłaniem się w metodologiczny „grzech" anachronizmu. Wczesna myśl indyjska zadowala się prostą odpowiedniością nazwa - przedmiot odniesienia, sprowadzającą się do

9 Oczywiście kwalifikując poszczególnych myślicieli do jednej grupy nie twierdzimy, że w rozwijanych przez nich koncepcjiach nie ma różnic. Zgodność występuje tutaj w przyjmowanej perspektywie badawczej. 
Michał Lipnicki: Magiczność Stowa we wczesnoindyjskiej refleksji nad językiem

konstatacji, że nazwa oznacza swój przedmiot odniesienia w sposób bezpośredni.

\section{Podsumowanie}

$\mathrm{W}$ artykule przedstawiliśmy najstarszy okres rozwoju myśli indyjskiej. Nie było naszym celem szukanie paralel $\mathrm{z}$ koncepcjami europejskimi, staraliśmy się raczej oddać jej charakter i wskazać na pewne cechy szczególne. Dlatego też odniesienia do filozofii europejskiej zostały ograniczone do niezbędnego minimum. Zgodnie $\mathrm{z}$ tym, co zostało zaznaczone we wstępie, staraliśmy się pokazać, że poprzez obserwację rozwoju refleksji nad językiem całkiem przekonujące uzasadnienie uzyskuje postulowana przez Stanisława Schayera magiczna geneza filozofii indyjskiej „w ogóle”. Poczynając od Wed, słowo jest połączone ze swoją denotacją magiczną mocą, dzięki której można wpływać na kształt rzeczywistości. Stopniowy, coraz bardziej intelektualny namysł nad istotą tej mocy doprowadził do pierwszych prób jej systematyzacji, która dokonała się w tekstach Brahmanów. Magiczna moc objawiała się na kilku poziomach istnienia, zależnie od typu homologii. W kwestii relacji nazwa przedmiot jej magiczność zeszła na dalszy plan, zastąpiona dwupoziomową homologią: nazwa (1) - nazwa (2), przedmiot odniesienia (1) - przedmiot odniesienia (2). Zasadność tego typu ekwiwalencji zasadza się na utożsamieniu nazwy z przedmiotem i niezmienności tej relacji. W ostatnim $\mathrm{z}$ omawianych okresów - Upaniszadach dokonało się ostateczne „odmagicznienie” relacji nazywania, zastępując magiczną ekwiwalencję związkiem, w którym nazwa stała się naturalną cechą przedmiotu oznaczanego. W historii myśli niezwykle rzadkie są sytuacje, gdy nowopowstała teoria jest całkowicie oderwana od wcześniejszego kontekstu filozoficznego, do którego w mniejszym lub większym stopniu nawiązuje. Dlatego też, co staraliśmy się w niniejszym artykule pokazać, wczesnoindyjskie koncepcje dotyczące natury języka są ściśle powiązane z wcześniejszymi intuicjami magicznymi. 


\section{Bibliografia}

Balcerowicz, P. 2003. Historia klasycznej filozofii indyjskiej. Warszawa: Dialog.

Burszta, W. 1991. Mowa magiczna jako przejaw synkretyzmu kultury. w: Język a Kultura, vol. 4. Wrocław. pp. 93-104

Burszta, W. 2009. Od mowy magicznej do szumów popkultury. Warszawa. Wydawnictwo SWPS Academica

Chapman, S. 2000. Philosophy for Linguists. An introduction. London, New York. Routledge

Dąmbska, I. 1984. Wprowadzenie do starożytnej semiotyki greckiej Studia $i$ teksty. Wrocław. Ossolineum

Frauwallner, E. 1990. Historia filozofii indyjskiej. Warszawa. PWN.

Guiraud, P. 1976. Semantyka. Warszawa. Wiedza Powszechna

Hymny Rigwedy. tłum. F. Michalski. Warszawa. Ossolineum. 1971.

Kieniewicz, J. 2003. Historia Indii. Wrocław. Ossolineum.

Kmita, J. 2001. Wprowadzenie. w: J. Kmita (ed.) Czy metamorfoza magiczna rekompensuje brak symbolu?. Poznań. Wydawnictwo Naukowe Instytutu Filozofii UAM

Koc, B. J. 2002. Wedyjska filozofia mowy (vāc). w: Studia indologiczne, vol. 9. Warszawa. pp. 19-71.

Koc, B. J. 2003. Hymny wedyjskie: Słowo i Mowa. w: Studia indologiczne, vol. 10. Warszawa. pp. 98-125.

Malinowski, B. 1990. Mit, magia, religia. Warszawa. PWN.

Malinowski. B. 1987. Ogrody koralowe i ich magia. Warszawa. PWN.

Platon, Kratylos. w: I. Dąbska Wprowadzenie do starożytnej semiotyki greckiej Studia i teksty. Wrocław. Ossolineum

Radhakrishnan, S. 1958. Filozofia indyjska. Warszawa. Instytut wydawniczy PAX.

Schayer, S. 1988. O filozofowaniu Hindusów. Warszawa. PWN.

Staal, F. 1975. The Concept of Metalanguage and its Indian Background. w: Journal of Indian Philosophy, vol. 3. pp. 315-354.

Staal, F. 2008. Discovering the Vedas. Orgins, Mantras, Rituals, Insights. New Delhi. Penguin Books India.

Upaniszady. tłum. M. Kudelska. Kraków. Wydawnictwo Uniwersytetu Jagiellońskiego. 2004.

Vidyabhusana. S. C. 1993. The Nyāya Sūtras of Gotama. New Delhi. Munshiram Manoharlal Publishers Pvt. Ltd. 